\title{
The Impact of Enhancing the Academic Performance on Student Satisfaction of Private Business Faculties: New Business Model for Egyptian Private Universities ${ }^{1}$
}

\author{
Dr. Samia Adly El Sheikh ${ }^{2}$ \\ Prof. Hosny Ibrahim Hamdy4
}

\author{
Prof. Yasser Tawfik Halim ${ }^{3}$
}

Dr. Mohamed Samy El-deeb 5

October University for Modern Scienes and Arts (MSA)

\begin{abstract}
The main purpose of the research is to test the direct and the indirect impact of the academic performance (represented by the academic staff, curriculum and the teaching assistants) on the overall satisfaction of business students in Egyptian private universities. Nowadays, student (customer) satisfaction is regarded as one of the main priorities to face intense competition between the new private universities in Egypt, and to attract high school graduates to join through favorable word of mouth. This is a quantitative study where primary data was collected using self-administered questionnaires from a sample of 1600 students from different business majors and with different GPA levels from four different business faculties in four Egyptian private universities in Greater Cairo. The suggested conceptual model was tested using the Structural Equation Modeling technique and the Lisrel software Ver8.54. Several goodness of fit indices shows the adequacy of the model. Satisfaction with TA's plays the mediator construct, where it is believed that students depend heavily on teaching assistants. Management of business private Universities in Egypt can make use of the empirical results of this research to enhance their understanding of the factors that impact student satisfaction and thus create differentiation in the provision of the university.
\end{abstract}

${ }^{1}$ Received in 3/6/2020, accepted in 11/7/2020.

${ }^{2}$ Lecturer,October University for Modern Sciences and Arts (MSA)(selsheikh@msa.eun.eg)

${ }^{3}$ Professor, October University for Modern Sciences and Arts (MSA) (ytawfik@msa.eun.eg)

${ }^{4}$ Professor, October University for Modern Sciences and Arts(MSA)(hosikhalel@ msa.eun. eg)

${ }^{5}$ Associate Professor, October University for Modern Sciences and Arts (MSA)

(msamy@msa.eun.eg) 
KeyWords: Student satisfaction, academic performance, Teaching Assistants, private universities, Structural Equation Modeling, factor analysis.

\section{INTRODUCTION}

Higher Education sector (H.E.) in Egypt is now experiencing a lot of drastic alterations. After passing through two revolutions, Egypt is in the process of developing its educational provision and turning it upside down. Since the allowance of private universities to function in Egypt, the competition has become severe among H.E. Institutions and each tries to develop a competitive advantage so as to differentiate their offer from other higher education institutions at a time when finally, private universities in Egypt are better trusted by people now (El Sheikh, 2019). Due to this severe competition, the time has come for H.E institutions to deal with students as customers and to ensure their satisfaction, which is an extremely important concern to create a sustainable competitive advantage needed to retain their existing students and to attract new students graduates of high schools. The importance of the quality of a service provided has become of utmost importance in case of severe challenge of competitiveness and sustainability in a time of globalization of every aspect including education (Santos, et al., 2020). Moreover, according to Arthur, (2020) faculty members are regarded as part of the Human Resources of the University and thus their performance is regularly measured.

\section{The Aim of the study}

The aim of this research is to study how private universities in Egypt can maintain their existing students and attract new ones by creating a competitive edge through ensuring customer (student) satisfaction with the academic performance of their university experience thus ensuring a sustainable income and profit and a better image and reputation.

This research deals with the role that academic performance plays in the Egyptian private universities and the need to increase student satisfaction through academic performance, to create positive perceived value for students.

The authors believe that intense competition and continuous students' demands create high students' (customers') expectations and this should 
encourage private universities to rethink of their business' practices and how to improve them as a unique selling proposition.

It is worth mentioning at the start, that this research deals only with the academic performance and curriculum aspects of the whole educational services that are the basis upon which any faculty and university depends on for achieving universities' goals that include presenting effective education and as such educational services represent 3 of the main constructs of this study which are:

- the academic staff (professor),

- the curriculum and

- the teaching assistants (TA).

However, the research didn't handle the nonacademic aspects of the university life that include the facilities of the university and the extracurricular activities, which are of very high importance yet could be studied in another research in the near future.

No one can deny that the teaching staff is a corner stone in any university and is the basis for educational services. As such the authors built 3 of constructs of their study on the academic performance and curriculum. Also, Croom (2003) stated that the quality of teaching staff in higher education institutions involve the individual characteristics of the staff members together with the structure of education system.

As for the fourth and important construct of this research, which is the dependent variable that the authors are aiming to investigate, it is satisfaction, or student satisfaction.

According to Mill, (2011) there are two widely known origin theories that deal with customer satisfaction which are disconfirmation paradigm and expectancy value concept. Both of which fall under the realm of theories of consumer behavior. Here, in this research the authors depended on the first of the two theories which is the Disconfirmation theory which indicates that customers compare their own service experience with a standard they had set in their minds. The theory assumes that customers decide to purchase the service on the basis of their expectations, attitudes, and intentions and later, during or after consumption, customers compare the actual service performance with 
their standard or expectation and the result is confirmation, satisfaction, or dissatisfaction.

Adnan, et al. (2016) cited that in many scholarly papers it was stated that student satisfaction is mainly dependent on the performance and abilities of the academic staff and that if students feel that their instructor cares and shows concern about their needs and their progress then this will further increase student satisfaction. Srivastav, et al. (2019) assure that students' satisfaction is the best indicator of educational services, and that student satisfaction has attracted considerable interest from education institutions that really care at building a sustainable competitive edge. These institutions' main challenge is to employ their resources so as to achieve highest possible customer satisfaction. Patten, et al. (2020), stated that measuring student satisfaction to indicate about quality in higher education should be a major concern of interest of private or even public university managers.

Many papers studied the factors that most affect students' satisfaction with particular emphasis on business students' satisfaction and it was found that academic factors such as the quality of teaching of the academic staff whether related to skills or knowledge of the instructors and the curriculum itself are the most significant determinants of overall satisfaction.

However, this study seeks to contribute by adding the benefit of teaching assistants (TAs) in the educational system and their mediator role that impact the satisfaction of students, which can lead to higher overall level of student satisfaction necessary in local private universities.

After this introduction which includes the aim of the study and an idea about the main constructs of the study and the added contribution that fills a gap in literature, the second section provides the research problem, then theoretical framework dealing with satisfaction and the educational services including the role of academic staff and the role of curriculum and finally the role of TAs, with the hypotheses development from each, followed by the conceptual research model. Section six describes the methodology, including the methods and tools used to test the hypotheses followed by a presentation of the research results in section 
seven. The final sections offer the main conclusions and suggestions for future research.

\section{RESEARCH PROBLEM}

Due to the intense competition between the new private universities in Egypt, each university tries to differentiate its products and services in order to maintain its existing students and to attract high school graduates to join. Nowadays, many universities set satisfaction of students as one of its main priorities to maximize the perceived value towards the university. Student satisfaction leads to favorable word of mouth, which in turn leads other favorable required outcomes as a positive brand image of the university and thus enhance the reputation of the university in the eyes of students and graduates.

In Egypt most of the private universities underestimate the academic performance, which has a crucial impact on the students' satisfaction. Therefore, the researchers investigated various factors of students' satisfaction in order to help enhancing the performance of the Egyptian Universities. In this research the authors (researchers) will focus on measuring the impact of academic aspects on student satisfaction towards the private universities in Egypt.

Moreover, the study investigates the role that Teaching Assistants (TAs) play in overall satisfaction of students towards their university; if they do have an impact on the satisfaction of students or not.

\section{THEORETICAL BACKGROUND AND HYPOTHESES DEVELOPMENT}

\subsection{Educational services with its components}

\subsubsection{Academic staff}

Marimon, et al. (2020); Calvo-Porral, et al. (2013) mentioned that educational services are those services that are offered by the universities or other higher education institutions as academies, research institutions and higher education institutes that aim at improving and upgrading the quality of higher education offered at university level. Educational services are those services that are the 
bases for application of educational policies necessary for achieving and enhancing the whole educational services.

There are several educational objectives related to educational services that are included but not restricted to the following:

- Structuring, reviewing and upgrading educational curriculums

- Improving teaching ways of teaching staff

- Ensuring a significant effective learning experience for the students

- Balancing the cost and benefits of the educational system to allow the best of effectiveness with least possible costs

- Encouraging that the students become self and continuous learners

- Enhancing innovation in learning

These objectives can only be achieved through measures that need to be undertaken by private universities that are directed towards upgrading the teaching skills and knowledge of the teaching staff and TAs and these measures include:

- Library services within the premises of the university that include materials directed towards enhancing the skills and knowledge of teaching staff.

- Information technology (IT) Infrastructure to assist teaching staff in their teaching and research.

- Continuous development training or workshops for teaching staff to update them with the latest in teaching and in their areas of specialization knowledge.

- The budget for participation in local and international conferences, or forums and the needed assistance to publish their research in refereed journals.

From the above the authors proposed the following hypotheses:

Ha-The academic performance has a direct effect on the student overall satisfaction in the Egyptian private universities.

Ha1- The academic staff has a significant direct effect on the TA performance in Egyptian private universities.

Ha2- The academic staff has a significant direct effect on the student overall satisfaction in Egyptian private universities. 


\subsubsection{Curriculum}

According to Alipio (2020); Lomas (2004) the good educational services depend on numerous factors starting from organizational values that favor quality of education; moving onto a staff body that accepts development and invites improvement in addition to being highly experienced in their areas of knowledge; to a well-built curriculum; moving on to a university management that believes in spending highly on fast improvement. The combination of these variables of values encouraging teacher's genre, student's genre and management that believes in improvement, all effectiveness and efficiency in teaching and learning. Furthermore, the level of teaching and learning together in an environment in which learning takes place all will lead to student satisfaction with the learning process.

McCaffery (2018); Aref \& Sabah (2015); Brown (2009); Abdul Rahim, (2015) noticed that the factors that are best indicators for academic staff teaching at a higher education institution are:

- how a course is built (structure) and curriculum

- teaching techniques

- Assessment techniques

- The relationship between the students and the instructor

Calvo-Porral, et al. (2013); Bazargan (1999) argue that the bases for education in universities of a country depends on the environment and governmental legislation under which a university carries out its tasks and depends on the skills and knowledge of the teaching staff and the students in addition to the curriculum and other resources available.

Thus, the authors hypothesized that:

Ha3- The curriculum has a significant direct effect on the TA performance in Egyptian private universities.

Ha4: The curriculum has a significant direct effect on the student overall satisfaction in Egyptian private universities.

HC2- The curriculum has significant positive total effect on overall satisfaction via satisfaction with TAs performance 


\subsection{Satisfaction}

The concept of customer satisfaction has initially been defined by Philip Kotler as how customer expectations are met. When trying to understand satisfaction, two concerns are balanced which are customer expectations and product or service performance. Thus, to what extent the customer's expectations are met decides the satisfaction or dissatisfaction level of the customer (Guterman, 2015).

Satisfaction could also be described as a process which starts with the formation of customers' expectations and ends with communication of the obtained experience. However, a person can be extremely subjective in how the service is assessed. Customers' expectations are highly affected by different internal and external factors. The higher the expectations are the more difficult it is for the company to satisfy customers and fulfill their needs. Thus satisfaction mainly depends on the balance between expected value versus delivered value. The consumer's level of expectation depends on the communicated value proposition of the business (Westerbeek \& Shilbury, 2003).

Hallencreutz \& Parmler (2019) pointed to customer satisfaction as it is one of the most important concepts in strategic marketing that has been well studied over many years. This concept of satisfaction has gained the concern from academicians, practitioners and businessmen who studied how to measure it and manage it. The consequences of satisfied customers include loyal behavior which is expressed in preference of the firm's products or services over those of its competitors. Moreover, satisfied customers are less price sensitive and are ready to communicate good word-of-mouth that would end in further attracting new customers. To sum up, customer satisfaction creates loyal customers which in turn leads to higher revenues and to better financial performance.

\subsubsection{Satisfaction with the academic staff}

Weerasinghe \& Dedunu, (2017) defined student satisfaction as a shortterm attitude towards the services provided by the higher education institution. This is a multidimensional construct that is highly influenced by university staff which can be categorized into academics and non- 
academics where the quality of teaching and learning are of paramount importance for academics and it determines the reputation and image of institute in long run. Thus academics performance in and outside classes is significant for students' motivation and satisfaction and finally loyalty. Thus teaching level has a statistically significant impact on students' satisfaction.

Stankovska, et al. (2017); Bentley, et al. (2013) cited that academic staff are main factors that lead to the success of any educational program. Thus ensuring satisfaction among academics is essential for the success of high educational institutions. Furthermore, a healthy climate at university increases not only the job satisfaction among academicians or the teaching staff, but it also increases the academicians' performance leading to higher student's satisfaction with the institution. There are different channels for measuring customer satisfaction or feedback, these include oral phone call surveys or written reviews that inform the business of any problems in its products and services and how to improve or develop them.

Adnan, et al. (2016); Balzer, (2020); Abdelsalam, et al. (2020); Eslami \& Gharakhani (2012) mentioned that the extent of satisfaction of students with academic performance is highly related to their perception of how it will affect them and support them in their future jobs and lives. Thus business professors have to implant the human touch and are incumbent to take at hand the very important tasks of upgrading curriculums that introduce requirements for success at work as team work, real life case studies and in class activities and encourage class discussion, that replicate market requirements. Moreover, a friendly, mentoring relationship encourages students to become independent learners and develop problem solving skills towards any problem that they might face in the future whether on the professional or personal level. In addition, the professor represents the role model in being punctual to lectures and keen to introduce up to date knowledge.

Dhaqane \& Afrah (2016); Tessema, et al. (2012) state that satisfaction has been highly studied in both academic and non-academic contexts. Many higher education institutions have measured their students' 
satisfaction with their syllabus which is an indirect indicator about the effectiveness of a program and this includes comprehensive exams by external examiners of external bodies.

Dong \& Lucey (2013) stated that there are different ways of assessing the quality of academic performance one of which, closing the loop through measuring student feedback of unit quality and another way of assessing the quality of education is through continuous assessment of student learning which is an important indicator and measure of student achievement. Moreover, students are asked to reflect on their learning experience and to express their level of satisfaction with the academic performance of their teachers.

Nugroho, (2020); Asaduzzaman, et al. (2014); Van Truong, et al. (2016) argue that higher education institutions need to study the factors that attract students and establish a competitive edge in light of the fierce competition that they face as student satisfaction ensures retaining existing students and attracting new ones through positive word of mouth from satisfied graduates who act as ambassadors of the institution which ensures further success and maintaining a stronger relationships with students.

Thus the authors hypothesized that:

Hc- Satisfaction with academic performance has a significant total effect on overall satisfaction via satisfaction with TAs performance

HC1-The academic staff has significant positive total effect on overall satisfaction via satisfaction with TAs performance.

\subsubsection{Satisfaction with Teaching Assistant (TA)}

Adnan, et al. (2016); Maddox \& Nicholson (2014) stated that teaching assistants' (TAs) role is enhancing the educational learning and that satisfaction with TAs performance depends on their capability to create an environment that encourages student learning and that adds to the main lecture in different ways as solving exercises, correcting assignments in a timely way and showing respect to the students and using office hours wisely. Moreover, the institution should hire or assign a sufficient number of TAs to ensure caring and concern for students. 
Shadiev \& Huang (2020); Berbegal Mirabent, et al. (2016) ensured that the teaching assistants (TA's) must possess the ability to explain the scientific content in a different way from the lecturers by offering new directions that can be used to improve students' understanding and inform them of different opinions which are difficult for lecturers to discuss within the limited time and large numbers of students in lectures. Since time is a scarce resource, faculty members tend to prioritize those activities that give better returns in terms of supporting educational outcomes, and therefore young academics who need to acquire an academic career are more in need of training to reduce the time and effort involved in teaching as it is considered to be one of the evaluation tools for good performance in teaching. Numerous studies indicate that students depend on TAs to understand complicated points of the curriculum and thus TAs support educational outcomes, and therefore TAs or young academics are an important tool that institutions can depend on to enhance student experience and satisfaction.

From the above the authors proposed that TAs performance has an impact on student satisfaction in the following hypothesis:

Ha5- Satisfaction with TA's performance has significant direct effect on overall satisfaction

Because of the important role of TAs, the authors proposed the mediating role of TAs performance, in the following hypotheses:

$\mathbf{H b}$-The academic performance has a significant indirect effect through a teaching assistant as a mediating on the student overall satisfaction in the Egyptian private universities.

Hb1-The academic staff has a significant indirect effect through a teaching assistant as a mediating on the student overall satisfaction in Egyptian private universities.

Hb2-The curriculum has a significant indirect effect through a teaching assistant as amediating on the student overall satisfaction in Egyptian private universities. 


\section{RESEARCH HYPOTHESES}

Ha-The academic performance has a direct effect on the student overall satisfaction in the Egyptian private universities.

Ha1- The academic staff has a significant direct effect on the TA performance in Egyptian private universities.

Ha2- The academic staff has a significant direct effect on the student overall satisfaction in Egyptian private universities.

Ha3- The curriculum has a significant direct effect on the TA performance in Egyptian private universities.

Ha4: The curriculum has a significant direct effect on the student overall satisfaction in Egyptian private universities.

Ha5- Satisfaction with TA's performance has significant direct effect on overall satisfaction

Hb-The academic performance has a significant indirect effect through a teaching assistant as a mediating on the student overall satisfaction in the Egyptian private universities.

Hb1-The academic staff has a significant indirect effect through a teaching assistant as a mediating on the student overall satisfaction in Egyptian private universities.

Hb2-The curriculum has a significant indirect effect through a teaching assistant as a mediating on the student overall satisfaction in Egyptian private universities.

Since there is a direct and indirect effect thus there will be a total effect: Hc-Satisfaction with academic performance has a significant total effect on overall satisfaction via satisfaction with TAs performance

Hc1-The academic staff has significant positive total effect on overall satisfaction via satisfaction with TAs performance.

Hc2- The curriculum has significant positive total effect on overall satisfaction via satisfaction with TAs performance. 


\section{THE CONCEPTUAL MODEL}

To verify the research hypotheses, the authors introduced the following conceptual model about the main effects of this study. Both satisfaction with professor's performance, and curriculum are the exogenous variables in the model, while TA performance plays the mediators, where it is believed that students depend heavily on the labs, problem sessions, and tutorials or sections which are mainly offered by teaching assistants. It is also suggested that both professors' performance and curriculum, affect overall satisfaction via the teaching assistants' performance. In other words, both exogenous effects are transmitted to the overall satisfaction through the teaching assistants' performance.

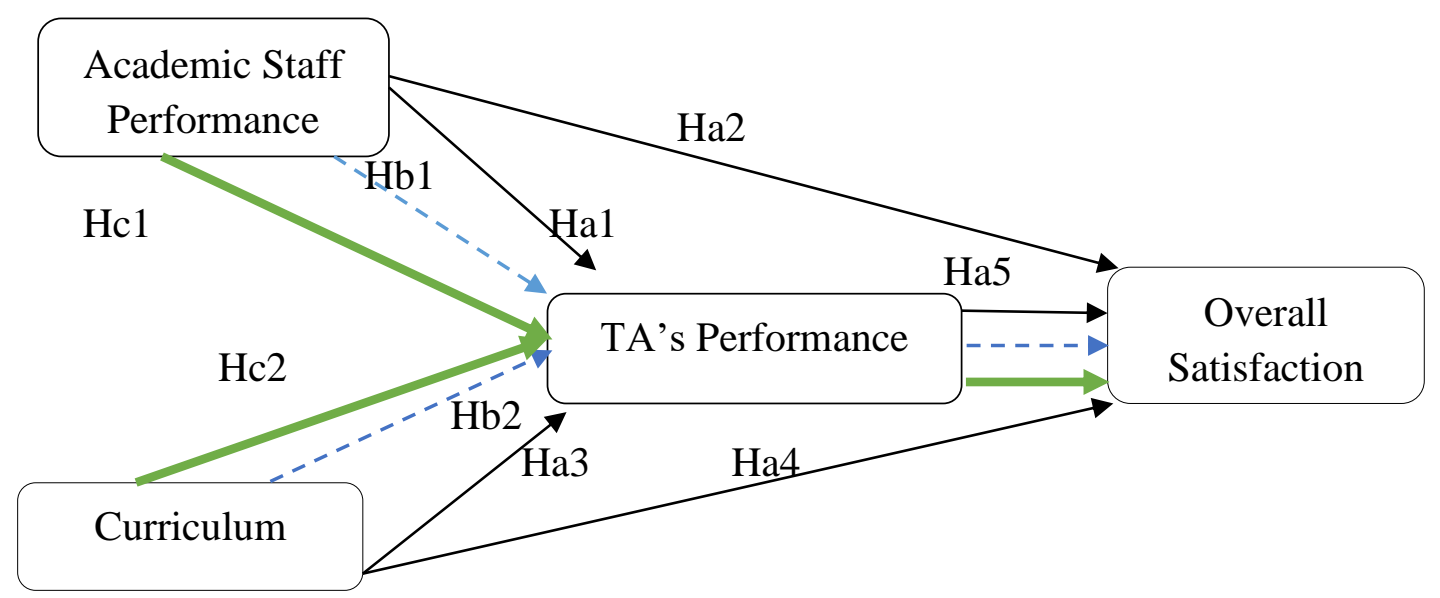

Figure 1: The conceptual model

\section{METHODOLOGY}

The authors (researchers) approach is a deductive approach where arguments are based on widely accepted theories or principles. Creswell and Plano Clark (2007) indicate that the deductive research starts from a theory down to hypotheses to data collection in order to add to or disprove an existing theory. In this research the authors adopted a deductive quantitative approach due to the fact that customer satisfaction theories are well established in the realm of consumer behavior. The researchers started by conducting a brief exploratory 
study that included an interview with the related parties of the study in order to gain insight into the problem and to ensure face validity of the issue under study. The next step was to use the results of previous literature and the exploratory interview to design the measurement tool (questionnaire) needed to collect data necessary to test the research hypotheses and the conceptual model.

\subsection{Population and Sample}

The population of the study covers all business or management students in various private higher education (HE) institutions, whether they are faculties of business administration or management sciences in private universities or in HE institutes or academies in Egypt. The population frame is quite big and exact figures are quite difficult to access. Although the authors are aware that probability samples as random samples are the best to give generalizable results from statistical analysis, yet this was out of reach and out of hand. As such the authors had to resort to other sample types from which results have to be treated cautiously yet they could give acceptable results and moreover, these non-probability sampling techniques are widely used in many if not most of social sciences researches. The authors applied judgmental sampling technique where respondents were selected from the third and fourth year only to be able to express a better opinion based on a longer experience at their universities (the business faculties of 4 private universities in Greater Cairo, namely: October University for Modern Sciences and Arts (MSA), Nile University, Al Ahram Canadian University and British University in Egypt (BUE).The selected respondents were from different business majors within the 4 private universities and that they are from the third or fourth year to be sure that they have been exposed and tried all the educational activities offered in their universities and thus are better able to judge about their satisfaction with educational services. The age that the researchers focused on was from 19 to 23, of both genders from junior and senior students thus they were not selected conveniently but the selection involved a random selection that follows the judgment of the researchers (Sekaran and Boujie, 2016). A sample of 1600 students from different business majors have been targeted in order to be able to better estimate the students' satisfaction of all different business majors. 
According to Hair et al., (2010) it is still true that the larger samples generally produce more stable solutions and for Structural Equations Modeling the sample size decisions are based on a set of factors so that models with large numbers of constructs and lower communalities and/or having fewer than three measured items have to have a large sample size of more than 500.

\subsection{Measurement Tool and Data Collection}

The questionnaire was adapted from different previous sources to ensure its validity and reliability. The questionnaire was pilot tested before distributing the final form to the respondents in Arabic and English languages. Pilot testing is a small-scale trial, where a few examinees take the test and comment on any problems with the test instructions, instances where items are not clear and formatting and other typographical errors and/or issues (Dikko, 2016).

The respondents were asked to answer the questionnaire using a faceto-face data collection technique. The data was collected by a selfadministered questionnaire using a face-to-face data collection technique. The questionnaires were distributed equally among 3 universities which are October University for Modern Sciences and Arts (MSA), Al Ahram Canadian University and British University in Egypt (BUE) with 550 questionnaires in each of the three but the number in Nile University was less than the others 100 only as the number of students in the faculty of business administration in Nile University are less. The questionnaires responded were 1600 with a $91.43 \%$ response rate. The time taken to collect the data was almost 7 weeks.

The researchers used a group of statistical techniques including descriptive analysis, factor analysis, Pearson correlation analysis and Structural Equation Modeling (SEM) path analysis to validate the research hypotheses, the statistical analysis and discussion are in the following section. 


\section{RESULTS AND DISCUSSION}

\subsection{Sample Characteristics}

Table 1: The Different Majors at Business Schools

\begin{tabular}{|c|l|c|c|c|c|}
\hline \multicolumn{2}{|c|}{} & Frequency & Percent & $\begin{array}{c}\text { Valid } \\
\text { Percent }\end{array}$ & $\begin{array}{c}\text { Cumulative } \\
\text { Percent }\end{array}$ \\
\hline \multirow{4}{*}{ Valid } & Accounting & 650 & 40.6 & 40.6 & 40.6 \\
\cline { 2 - 6 } & Marketing & 520 & 32.5 & 32.5 & 73.1 \\
\cline { 2 - 6 } & Economics & 220 & 13.8 & 13.8 & 86.9 \\
\cline { 2 - 6 } & MIS \& Finance & 210 & 13.1 & 13.1 & 100.0 \\
\cline { 2 - 6 } & Total & 1600 & 100.0 & 100.0 & \\
\hline
\end{tabular}

The percentage of respondents are almost 40.6\% from Accounting Department and 32.5\% from Marketing Department. 13.5\% from the Economics Department, and $13.1 \%$ from Management Information Systems (MIS) and Finance Departments. The sample selected was representative regarding the different departments of business schools in private universities.

Table 2: The Gender of Respondents

\begin{tabular}{|c|l|c|c|c|c|}
\hline \multicolumn{2}{|c|}{} & $\begin{array}{c}\text { Frequenc } \\
\mathbf{y}\end{array}$ & Percent & $\begin{array}{c}\text { Valid } \\
\text { Percent }\end{array}$ & $\begin{array}{c}\text { Cumulative } \\
\text { Percent }\end{array}$ \\
\hline \multirow{3}{*}{ Valid } & female & 730 & 45.6 & 45.6 & 45.6 \\
\cline { 2 - 6 } & male & 870 & 54.4 & 54.4 & 100.0 \\
\cline { 2 - 6 } & Total & 1600 & 100.0 & 100.0 & \\
\hline
\end{tabular}

The percentage of respondents are almost stratified with a $45.6 \%$ are female students and $54.4 \%$ are male students. This showed the diversity of the responses regarding the different genders and that both males and females are represented almost quite equally in the sample.

Table 3: GPA GROUPS

\begin{tabular}{|c|l|c|c|c|c|}
\hline \multicolumn{2}{|c|}{} & $\begin{array}{c}\text { Frequenc } \\
\text { y }\end{array}$ & Percent & $\begin{array}{c}\text { Valid } \\
\text { Percent }\end{array}$ & $\begin{array}{c}\text { Cumulative } \\
\text { Percent }\end{array}$ \\
\hline \multirow{5}{*}{ Valid } & GPA < 2.665 & 400 & 25.0 & 25.0 & 25.0 \\
\cline { 2 - 6 } & $\begin{array}{l}2.665<\mathrm{GPA}<= \\
3.19\end{array}$ & 400 & 25.0 & 25.0 & 50.0 \\
\cline { 2 - 6 } & $\begin{array}{l}3.19<\mathrm{GPA} \\
<=3.585\end{array}$ & 400 & 25.0 & 25.0 & 75.0 \\
\cline { 2 - 6 } & GPA > 3.585 & 400 & 25.0 & 25.0 & 100.0 \\
\cline { 2 - 6 } & Total & 1600 & 100.0 & 100.0 & \\
\hline
\end{tabular}


The percentage of respondents are almost $25 \%$ for each of the GPA groups GPA $<2.665,2.665<$ GPA $<=3.19,3.19<$ GPA $<=3.585$ and GPA $>$ 3.585). the percent of respondents covered all the different GPA levels which confirm the representation of all the students' academic level in the sample.

\subsection{Student Satisfaction with Academic performance}

\subsubsection{Factor Analysis}

Factor analysis is a statistical technique that is devised mainly to reduce large data set into less number of latent variables called factors. It includes relevant variables (indicators) analysis through the correlation between variables. The correlation between a variable and a factor is known as factor loading. The procedure extracts the maximum variance from all variables through the Eigen values which is known as the (explained variance). In exploratory factor analysis, the technique is used to reveal patterns between different variables to form constructs (trait). It is utilized also to remove redundancy between variables, which is important when the analysis requires removing singularity in data in case of multicollinearity. The following table (4) presents the results of factor analysis, which includes the factor loading of each factor, reliability, and the extracted variance. It also provides, the mean of each factor, its standard error, and the p-value in testing the hypothesis that the average of the responses is neutral for each factor using the t-test. 
Table 4: Factor Analysis for Data Reduction

\begin{tabular}{|c|c|c|c|c|c|c|}
\hline Factors & $\begin{array}{l}\text { Factor } \\
\text { Loadings }\end{array}$ & Reliability & $\begin{array}{l}\text { Extracted } \\
\text { variance }\end{array}$ & $\begin{array}{c}\text { The } \\
\text { Average }\end{array}$ & $\begin{array}{c}\text { The } \\
\text { Standard } \\
\text { Error } \\
\end{array}$ & $\begin{array}{c}\text { P- } \\
\text { value }\end{array}$ \\
\hline $\begin{array}{l}\text { Satisfaction } \\
\text { with } \\
\text { Professors }\end{array}$ & & $82.3 \%$ & $73.98 \%$ & & & \\
\hline $\mathrm{A} 4$ & .881 & & & 4.15 & 1.017 & $.000^{*}$ \\
\hline A5 & .833 & & & 4.28 & .863 & $.000^{*}$ \\
\hline A6 & .866 & & & 4.28 & .959 & $.000 *$ \\
\hline $\begin{array}{l}\text { Satisfaction } \\
\text { with } \\
\text { Curriculum }\end{array}$ & & $82.6 \%$ & $74.63 \%$ & & & \\
\hline B17 & .840 & & & 3.70 & 1.132 & $.000^{*}$ \\
\hline B18 & .878 & & & 3.81 & .979 & $.000^{*}$ \\
\hline B19 & .872 & & & 3.82 & .977 & $.000 *$ \\
\hline $\begin{array}{l}\text { Satisfaction } \\
\text { with Teaching } \\
\text { Assistant }\end{array}$ & & $84.2 \%$ & $83.18 \%$ & & & \\
\hline Qc23 & .909 & & & 4.28 & .938 & $.000^{*}$ \\
\hline Qc24 & .893 & & & 4.27 & .923 & $.000^{*}$ \\
\hline Qc25 & .934 & & & 4.34 & .911 & $.000 *$ \\
\hline $\begin{array}{l}\text { Overall } \\
\text { Satisfaction }\end{array}$ & & $87.7 \%$ & $80.37 \%$ & & & \\
\hline QI55 & .896 & & & 4.10 & .953 & $.000 *$ \\
\hline QI57 & .910 & & & 4.19 & .870 & $.000^{*}$ \\
\hline QI58 & .883 & & & 4.34 & .868 & $.000^{*}$ \\
\hline
\end{tabular}

- Means the difference between the average and 3 (neutral) is significant at $\alpha<0.05$.

\section{Explanation:}

As shown in Table (4) the reliability of all constructs are greater than $82 \%$, and the extracted variances are greater the $73 \%$, which satisfy the requirements of both validity and reliability of our instruments (Hair et al., 1998).

Moreover, the students are strongly satisfied with professors' performances (all means are larger than 4, with p-values are less ten 0.05), satisfied with curriculum (all means are greater than 3.5 with pvalues less than 0.05), satisfied with TA's performance (all means are greater than 4 with p-values less than 0.05 ), and finally they are satisfied 
with all educational academic activities (all means are greater than 4 , with p-values less than 0.05 .

Table (5) presents the statistical summary measures of the main constructs in terms of the means, the standard deviation, and the standard error of the mean, the coefficient of variation, and the p-value of testing whether the overall means equal three (neutral). As indicated in Table (5) all means are significantly greater the 3 , which illustrate strong satisfaction of students to the academic process at business school.

Table 5: Statistical summary measures of the main constructs

\begin{tabular}{|l|c|c|c|c|c|}
\hline \multicolumn{1}{|c|}{ Constructs } & Mean & $\begin{array}{c}\text { Standard } \\
\text { Deviation }\end{array}$ & $\begin{array}{c}\text { Standard } \\
\text { Error }\end{array}$ & $\begin{array}{c}\text { The Coefficient } \\
\text { of Variation }\end{array}$ & $\begin{array}{c}\text { P- } \\
\text { value }\end{array}$ \\
\hline $\begin{array}{l}\text { Satisfied with } \\
\text { Professor } \\
\text { Performance }\end{array}$ & 4.24 & 0.82 & 0.06 & $81.51 \%$ & .000 \\
\hline $\begin{array}{l}\text { Satisfied with } \\
\text { Curriculum }\end{array}$ & 3.78 & 0.89 & 0.07 & $23.52 \%$ & .000 \\
\hline $\begin{array}{l}\text { Satisfied with TA } \\
\text { Performance }\end{array}$ & 4.30 & 0.84 & 0.07 & $19.61 \%$ & .000 \\
\hline Overall Satisfaction & 4.21 & 0.80 & 0.06 & $19.12 \%$ & .000 \\
\hline
\end{tabular}

- Means the difference between the average and 3 (neutral) is significant at $\alpha<0.05$. Table (5) presents the overall means of the main constructs, its standard deviation, the coefficient of variation, and the p-value of testing the overall means are neutral (equal to 3 on 5 liker scale).

\section{Explanation:}

As shown all means are significant, which indicates that the students are satisfied with professors' performance, curriculum, with TA performance, and overall satisfaction (all p-values are $<0.05$ ). See the graphical display in Fig (2) for more illustration. 


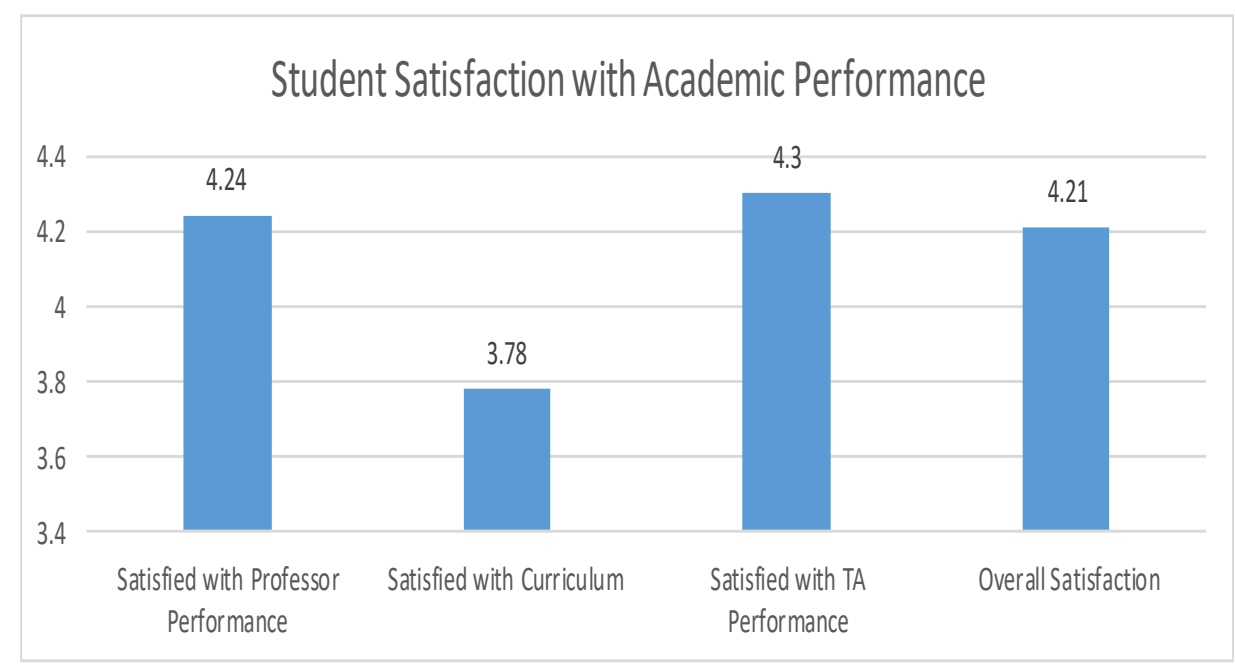

Figure 2: Student Satisfaction with Academic Performance

\subsection{The Fitted Model}

Having decided for the most reliable and valid items to measure the main constructs (research variables) as presented in Table (4) above, we have tried to fit the data to the proposed model against several alternatives, using the Structural Equation Modeling (SEM) statistical technique and the Lisrel software Ver8.54.

Results:

To test the conceptual model, we used several goodness of fit indices were applied.

As per Hair et al., (2010) the results of different indexes show the adequacy of the model including: Normed Fit Index (NFI) $=0.91$, NonNormed Fit Index $(\mathrm{NNFI})=0.91$, Parsimony Normed Fit Index $(\mathrm{PNFI})=$ 0.67, Comparative Fit Index (CFI) $=0.93$, Incremental Fit Index (IFI) $=$ 0.93, Root Mean Square Residual (RMR) $=0.048$ recommended 0.05 or less, Standardized RMR $=0.048$, Goodness of Fit Index (GFI) $=0.86$ recommended 0.85 or more, Adjusted Goodness of Fit Index (AGFI) = 0.81 , recommended 0.80 or more 


\section{Explanation:}

From the above results it can be seen that the conceptual model of the study fits well by evidence of the various fit indexes which are all within the required to fit.

\subsection{The Correlation Matrix between Research Variables}

Before we discuss the casual relationship between the research variables, we would to discuss the nature of the association between them. Correlation, $(-1 \leq r \leq 1)$, is a measure of association between pairs of variables. It measures by its magnitude the strength of the relations, and by its sign the direction of the relations.

Table 6: Correlation Matrix between Research Variables

\begin{tabular}{|l|c|c|c|}
\hline Reassert Variables & $\begin{array}{c}\text { TA's } \\
\text { Performance }\end{array}$ & $\begin{array}{c}\text { Professors } \\
\text { Performance }\end{array}$ & Curriculum \\
\hline TA's Performance & 1 & & \\
\hline $\begin{array}{l}\text { Professors } \\
\text { Performance }\end{array}$ & 0.38 & 1 & \\
\hline P-value & 0.000 & & \\
\hline Curriculum & 0.57 & 0.52 & 1 \\
\hline P-value & 0.000 & 0.000 & \\
\hline Overall & 0.62 & 0.58 & 0.69 \\
\hline P-value & 0.000 & 0.000 & 0.000 \\
\hline
\end{tabular}

\section{Explanation:}

As illustrated in Table (6), there is weak positive but significant correlation between satisfaction with satisfaction with TA's performance and satisfaction with professor's performance $(r=0.38$, p-value $=0.000)$, strong positive and significant correlation between satisfaction with TA's performance, and satisfaction with curriculum ( $r=0.57$, p-value $=$ 0.000), and strong positive and significant correlation between satisfaction with TA's performance and the overall satisfaction $(r=0.62$, $\mathrm{p}$-value $=0.000$ ). Satisfaction with professor performance has strong positive and significant correlation with satisfaction with curriculum $(r$ $=0.52$, $\mathrm{p}$-value $=0.000$ ), and strong positive and significant correlation with overall satisfaction $(r=0.58, p$-value $=0.000)$. Finally, there is strong positive and significant correlation between satisfaction with curriculum and the overall satisfaction $(r=0.69$, p-value $=0.000)$. 


\subsection{Construct Reliability (CR) and the Average Variance Extracted} (AVE)

Construct reliability (composite reliability) is a measure of internal consistency between instruments (items). Brunner and SÜ $\beta$ (2005) defined it as the relation of the total amount of true score variance to the total amount of scale scores variance see also Furnner and Lacker (1981). Construct reliability of $70 \%$ or more are deemed acceptable (Hair, et al., 1998). As shown in Table (11) all reliabilities are greater than $85 \%$ which insure strong internal consistency between research items for each construct. Cr reliability is computed through the formula $\mathrm{CR}=\frac{\left(\sum \lambda_{i}\right)^{2}}{\left(\sum \lambda_{i}\right)^{2}+\sum\left|\varepsilon_{i}\right|}$, where, $\lambda_{i \prime s}$ and $\varepsilon_{i \prime s}$ are the completely standardized loadings for the $i^{t h}$ indicator, and the error term for the $i^{\text {th }}$ indicator respectively. Both $\lambda_{i \prime s}$ and $\varepsilon_{i \prime s}$ are among Lisrel output.

Table 7: The Construct Reliability (CR) and the Average Variance Explained (AVE)

\begin{tabular}{|l|c|c|c|}
\hline \multicolumn{1}{|c|}{ Construct } & CR & AVE & $\boldsymbol{R}^{\mathbf{2}}$ \\
\hline Satisfaction with TA's Performance & $93.8 \%$ & $83.4 \%$ & $33 \%$ \\
\hline Satisfaction with Professor's Performance & $85.9 \%$ & $67.14 \%$ & ----- \\
\hline Satisfaction with Curriculum & $86.3 \%$ & $67.75 \%$ & ---- \\
\hline Overall Satisfaction & $97.2 \%$ & $77.8 \%$ & $66 \%$ \\
\hline
\end{tabular}

The average variance extracted on the other hand is a measure of the amount of variance that is captured by a construct in relation to the amount of variance due to measurement error. The average variance extracted has often been used to assess the lack of discriminant validity (Henseler, et al., 2015); (Voorhees, et al., 2016). AVE greater than 50\% is consider acceptable, (Hair et al., 1998). As sown in Table (4) all AVE are greater than $67 \%$ which indicated excellent convergent validity of these constructs. The AVE is calculated by the formula, $\operatorname{AVE}=\frac{\sum\left(\lambda_{i}{ }^{2}\right)}{\sum\left(\lambda_{i}{ }^{2}\right)+\sum\left|\varepsilon_{i}\right|}$

\subsection{Discriminant Validity between Constructs}

Discriminant validity is the degree to which two conceptually similar concepts are distinct (Henseler, et al., 2015). The discriminant validity between two constructs $X$, and $Y$, is measured by $D V_{X, Y}=\frac{r_{X, Y}}{\sqrt{C R_{X} C R_{Y}}}$, where 
$r_{X, Y}$ is the correlation between $X$, and $Y, C R_{X}$ and, $C R_{Y}$ are the composite reliabilities of $X$ and $Y$ respectively. $D V_{X, Y}$ of $85 \%$ and above is strong evidence of lack of discriminant validity between the two constructs.

Table 8: Discriminant Validity between Constructs

\begin{tabular}{|l|c|c|c|}
\hline \multicolumn{1}{|c|}{ Reassert Variables } & $\begin{array}{c}\text { TA's } \\
\text { Performance }\end{array}$ & $\begin{array}{c}\text { Professors } \\
\text { Performance }\end{array}$ & Curriculum \\
\hline TA's Performance & 1 & & \\
\hline Professors Performance & $42.34 \%$ & 1 & \\
\hline Curriculum & $63.35 \%$ & $60.40 \%$ & 1 \\
\hline Overall & $64.93 \%$ & $60.74 \%$ & $75.34 \%$ \\
\hline
\end{tabular}

As illustrated in Table (8), the non -existence of lack of discriminant validity.

\subsection{Path Analysis and the assertion of Research Hypotheses.}

Table 9: Path Analysis and the verification of Research Hypotheses.

\begin{tabular}{|c|c|c|c|c|c|c|}
\hline Effects & $\begin{array}{l}\text { Path } \\
\text { Coeff }\end{array}$ & $\begin{array}{c}\text { Standard } \\
\text { error }\end{array}$ & $\begin{array}{c}\mathrm{t}- \\
\text { value }\end{array}$ & $\begin{array}{c}\text { p- } \\
\text { value }\end{array}$ & Hypothesis & Significance \\
\hline \multicolumn{7}{|l|}{ The Direct Effect } \\
\hline $\begin{array}{l}\text { Professor } \longrightarrow \\
\text { TA's }\end{array}$ & 0.12 & 0.09 & 1.29 & 0.099 & $H_{a 1}$ & $\begin{array}{c}\text { Not } \\
\text { Supported }\end{array}$ \\
\hline $\begin{array}{l}\text { Professor } \longrightarrow \\
\text { Overall }\end{array}$ & 0.27 & 0.08 & 3.52 & 0.000 & $H_{a 2}$ & Supported \\
\hline $\begin{array}{l}\text { Curriculum } \longrightarrow \\
\text { TA's }\end{array}$ & 0.51 & 0.10 & 5.29 & 0.000 & $H_{a 3}$ & Supported \\
\hline $\begin{array}{l}\text { Curriculum } \longrightarrow \\
\text { Overall }\end{array}$ & 0.37 & 0.09 & 4.07 & 0.000 & $H_{a 4}$ & Supported \\
\hline $\begin{array}{l}\text { TA's } \quad \longrightarrow \\
\text { Overall }\end{array}$ & 0.31 & 0.08 & 4.01 & 0.000 & $H_{a 5}$ & Supported \\
\hline \multicolumn{7}{|c|}{ The Indirect Effect } \\
\hline $\begin{array}{l}\text { Professor } \longrightarrow \\
\text { Overall }\end{array}$ & 0.04 & 0.03 & 1.23 & 0.109 & $H_{b 1}$ & $\begin{array}{c}\text { Not } \\
\text { Supported }\end{array}$ \\
\hline $\begin{array}{l}\text { Curriculum } \longrightarrow \\
\text { Overall }\end{array}$ & 0.16 & 0.05 & 3.32 & 0.000 & $H_{b 2}$ & Supported \\
\hline \multicolumn{7}{|l|}{ Total Effect } \\
\hline $\begin{array}{l}\text { Professor } \longrightarrow \\
\text { Overall }\end{array}$ & 0.31 & 0.08 & 3.71 & 0.000 & $H_{c 1}$ & Supported \\
\hline $\begin{array}{l}\text { Curriculum } \longrightarrow \\
\text { Overall }\end{array}$ & 0.52 & 0.09 & 5.99 & 0.000 & $H_{c 2}$ & Supported \\
\hline
\end{tabular}




\subsection{Regarding Direct Effects}

Satisfaction with professor has $12 \%$ insignificant direct effect on Satisfaction with TA's p-value 0.099, which does not support the hypothesis $H_{a 1}$, while it has $27 \%$ significant direct effect on overall satisfaction $(\mathrm{p}$-value $=0.000)$ which asserts the hypothesis $H_{a 2}$.

Satisfaction with curriculum, has 51\% significant direct effect on both satisfaction with TA's performance, p-value 0.000 , which validates $H_{a 3}$, and it has $37 \%$ significant direct effect on overall satisfaction, $\mathrm{p}$-value = 0.000 , which justifies $H_{a 4}$.

Finally, satisfaction with TA's performance has 31\% significant direct effect on overall satisfaction, p-value 0.000 , which approves the hypothesis $H_{a 5}$.

\subsection{Regarding the Indirect Effect}

Satisfaction with professor performance, has no significant indirect effect on overall satisfaction $4 \%$, p-value, 0.109 , which disprove the hypothesis $H_{b 1}$, while satisfaction with curriculum has $21 \%$ significant indirect effect on overall satisfaction, $\mathrm{p}$-value $=0.000$, which confirms $H_{b 2}$.

\subsection{Total Effects}

Satisfaction with professor's performance has 31\% positive significant total effect on overall satisfaction via satisfaction with TAs performance ( $\mathrm{p}$-value $=0.000$ ) which substantiates $H_{c 1}$. Satisfaction with curriculum has $51 \%$ positive significant effect on overall satisfaction via satisfaction with TAs performance, ( $\mathrm{p}$-value 0.000 ), which authenticates $H_{c 2}$.

\section{8- CONCLUSION AND IMPLICATIONS}

The main purpose of the research was to test the direct and the indirect relationship among the academic performance represented by the academic staff, curriculum and the teaching assistant and the overall satisfaction in the business faculties of Egyptian private universities. The researchers collected data from a primary source from a sample of 1600 students from different genders and with different GPA levels and from different Egyptian private universities. The data collected was analyzed 
using different statistical tests; descriptive analysis, factor analysis and path analysis to verify the hypotheses. The results of the analysis supported the hypotheses of the research except for the direct effect of professor on TAs and indirect effect of professor on overall satisfaction.

Thus satisfaction with TA's performance plays the mediators role where the students depend heavily on the labs, problem session, and tutorial which mainly offered by teaching assistants. The researchers also believe that both satisfaction with professors' performance and satisfaction with curriculum, affect overall satisfaction via the satisfaction with teaching assistants' performance. In other words, both exogenous effects are transmitted to the overall satisfaction through the satisfaction with teaching assistants.

\subsection{From a practical managerial implication concern}

- Since satisfaction with TA's performance has 31\% significant direct effect on overall satisfaction, p-value 0.000 , which proves the important role that TAs play in the educational process and at the same time has an important role in the overall satisfaction of the students who are the main customers of private higher education institutions or universities.

- From this result of the study, the researchers advise the management of private universities to create a competitive advantage by relying on TAs in the tutorial section time not only in office hours in addition to their instructors as the students depend on them (TAs) in the application and problem solving aspects of the assessment and represent the link between the academic staff and the students as they are younger and students can ask them more freely to re explain the difficult parts of the curriculum, thus the students get a better fit with their curriculum and enjoy learning more, which leads to better exam results.

- Thus, to achieve the goal of high overall satisfaction of students (customers) which leads to positive word of mouth by students and graduates and this helps to retain existing students so that they don't switch to other universities and attract new ones, private universities should depend on TAs and further invest in them to enhance their 
knowledge and skills as they are the future professors who are also the main factor that lead to satisfaction of students.

- Furthermore, the establishment of friendly educational atmosphere of TAs help in enhancing student learning and in developing cognitive and intellectual and personal skills that lead them to become independent learners.

- Moreover, due to the fact that the level of student satisfaction with the university highly depends on their satisfaction with academic performance in the form of staff and TAs who convince the students that the knowledge and skills that they will gain will better prepare them for a successful future career, thus private universities must further spend on training and development of staff as Business school professors are the main factor in fulfilling the expectation of students with regards to preparing them for the job market requirements.

\subsection{From a theoretical implication concern}

The research results go hand in hand with the previous literature regarding the important role of the academic staff and the curriculum in the overall satisfaction of students with the university as in (Weerasinghe \& Dedunu, 2017); (Dong \& Lucey, 2013); (McCaffery, 2018); (Aref \& Sabah, 2015); (Brown, 2009). The results of the study prove the satisfaction with professor performance has strong significant correlation with satisfaction with curriculum and strong significant positive correlation with overall satisfaction. This emphasizes the previously mentioned literature. Finally, there is strong significant positive correlation between satisfaction with curriculum and the overall satisfaction.

\section{RESEARCH LIMITATIONS AND SUGGESTIONS FOR FUTURE RESEARCH}

- A major limitation of this research is that it deals only with the academic performance of the Educational services that are primary factors that enable universities to reach their goals and build a reputation and a brand name for effective education and are the 3 main constructs of this study (the professor, the curriculum and the TA), yet the research didn't handle the nonacademic aspects of the 
university life that include the facilities of the university and the extracurricular activities; as such a suggestion for further research is to handle the nonacademic aspects of the university and their impact on students' overall satisfaction level with their business faculties.

- Moreover, the study mainly deals with the satisfaction of business students with delivered academic performance, thus another suggestion for further research is to apply the study on other faculties of private universities as dentistry, pharmacy, engineering and mass communication or other in order to check if the results are the same and that the role of TA could lead to high satisfaction level among students.

- Another limitation is that the study was conducted on four private universities in Greater Cairo and a suggestion for further research is to replicate the study on other private universities in different governorates of Egypt as now there are many private universities in different parts of Egypt as in Alexandria, Sinai and in the near future we will have other private higher education institutions in El Gouna, Sharm El Sheikh, Al Alamein and El Galala and other.

\section{REFERENCES}

Abdelsalam, M.; Rodriguez, T. E., \& Brallier, L. (2020). Student and Faculty Satisfaction with Their Dental Curriculum in a Dental College in Saudi Arabia. International Journal of Dentistry, 2020.

Abdul Rahim, R. (2015). Analyzing manpower data of higher learning institutions: A Markov chain approach. International Journal of Human Resource Studies, 5(3), 38-47.

Adnan, A. R.; Mohamed, A. F.; Tarek, A.; Mun, S., \& Hosny, H. (2016). Measuring student satisfaction with performance enhancement activities: Evidence from business education. International Journal of Information and Education Technology, 6(10). 
Alipio, M. (2020). Academic Adjustment and Performance among Filipino Freshmen College Students in the Health Sciences: Does Senior High School Strand Matter?

Aref, M., \& Sabah, M. (2015). Manpower planning for demand forecasting of faculty members using trend analysis and regression. International Journal of Academic Research in Business and Social Sciences, 5(2), 11.

Arthur, L. (2020). Evaluating student satisfaction-restricting lecturer professionalism: outcomes of using the UK national student survey questionnaire for internal student evaluation of teaching. Assessment \& Evaluation in Higher Education, 45(3), 331-344.

Asaduzzaman, M.; Hossain, M., \& Rahman, M. (2014). Service quality and student satisfaction: a case study on private universities in Bangladesh. International Journal of Economics, Finance and Management Sciences, 1(3), 128.

Balzer, W. K. (2020). Lean higher education: Increasing the value and performance of university processes. CRC Press.

Bazargan, A. (1999). Introduction to assessing quality in higher medical education in Iran: Challenges and perspectives. Quality in higher education, 5(1), 61-67.

Bentley, P. J.; Coates, H.; Dobson, I. R.; Goedegebuure, L., \& Meek, V. L. (2013). Factors associated with job satisfaction amongst Australian university academics and future workforce implications. In Job satisfaction around the academic world (29-53). Springer, Dordrecht.

Berbegal Mirabent, J.; Mas Machuca, M., \& Marimón Carvajal, F. (2016). The impact of the lecturer experience on the student satisfaction. In Proceedings book of the 2nd International Conference on Quality Engineering and Management, 2016 (3248). 
Brown, A. V. (2009). Students' and teachers' perceptions of effective foreign language teaching: A comparison of ideals. The Modern Language Journal, 93(1), 46-60.

Brunner, M., \& SÜß, H. M. (2005). Analyzing the reliability of multidimensional measures: An example from intelligence research. Educational and Psychological Measurement, 65(2), 227-240.

Calvo-Porral, C.; Lévy-Mangin, J. P., \& Novo-Corti, I. (2013). Perceived quality in higher education: an empirical study. Marketing Intelligence \& Planning, 31(6), 601-619.

Cheng, Y.C. (2003). Quality assurance in education: internal, interface, and future. Quality Assurance in Education, 11(4), 202-213.

Creswell, J.W., \& Plano Clark, V.L. (2007). Designing and conducting mixed methods research. Thousand Oaks, CA: Sage Publications

Croom, D. B. (2003). Teacher burnout in agricultural education. Journal of Agricultural Education, 44(2), 1-13.

Dhaqane, M. K., \& Afrah, N. A. (2016). Satisfaction of Students and Academic Performance in Benadir University. Journal of Education and Practice, 7(24), 59-63.

Dikko, M. (2016). Establishing construct validity and reliability: Pilot testing of a qualitative interview for research in Takaful (Islamic Insurance). The Qualitative Report, 21(3), 521-528.

Dong, Y., \& Lucey, A. (2013). Relationships between student satisfaction and assessment grades in a first-year engineering unit. In Design, develop, evaluate: The core of the learning environment. Proceedings of the 22nd Annual Teaching and Learning Forum (1-10). Murdoch University.

El Sheikh, S. (2019) How engaged customers can help the brand: an empirical case study on a higher education institution (university) in Egypt, International Journal of Marketing Studies, 11(1) (ISSN \# 1918-719X \& 1918-7203). 
Eslami, J. and Gharakhani, D., (2012). Organizational commitment and job satisfaction. ARPN Journal of Science and Technology, 2(2), 85-91.

Guterman, Y. (2015), Customer satisfaction evaluation and recommendations for a marketing communication, Case: Business-Hotel "Karelia", MAMK,

http://www.theseus.fi/bitstream/handle/10024/102420/thesis_Guter man.pdf;jsessionid=CFD5C38FFB105CE3D11E21BA4893D 4 E8?sequence=1 [access: 20.11.2017].

Ghonji, M.; Khoshnodifar, Z.; Hosseini, S. M., \& Mazloumzadeh, S. M. (2015). Analysis of some effective teaching quality factors within faculty members of agricultural and natural resources colleges in Tehran University. Journal of the Saudi society of agricultural sciences, 14(2), 109-115.

Hair, J.F.; Black, W.C.; Babin, B.J. and Anderson, R.E. (2010). Multivariate data analysis A global perspective .Upper Saddle River, NJ: Pearson Prentice Hall.

Hair, J.F.; Black, W.C.; Babin, B.J.; Anderson, R.E. and Tatham, R.L. (1998). Multivariate data analysis 5 (3). (207-219). Upper Saddle River, NJ: Prentice hall.

Hallencreutz, J., \& Parmler, J. (2019). Important drivers for customer satisfaction-from product focus to image and service quality. Total quality management \& business excellence, 1-10.

Henseler, J.; Ringle, C. M., \& Sarstedt, M. (2015). A new criterion for assessing discriminant validity in variance-based structural equation modeling. Journal of the academy of marketing science, 43(1), 115-135.

Lomas, L. (2004). Embedding Quality: The Challenges for Higher Education. Quality Assurance in Education: An International Perspective, 12(4), 157-165. 
Maddox, E. N., \& Nicholson, C. Y. (2014, January). The business student satisfaction inventory (BSSI): Development and validation of a global measure of student satisfaction. In Developments in Business Simulation and Experiential Learning: Proceedings of the Annual ABSEL conference (35).

Marimon, F.; Mas-Machuca, M., \& Berbegal-Mirabent, J. (2020). Fulfilment of expectations on students' perceived quality in the Catalan higher education system. Total Quality Management \& Business Excellence, 31(5-6), 483-502.

Matzler, K.; Sauerwein, E., \& Heischmidt, K. (2003). Importanceperformance analysis revisited: the role of the factor structure of customer satisfaction. The Service Industries Journal, 23(2), 112-129.

McCaffery, P., (2018). The higher education manager's handbook: effective leadership and management in universities and colleges. Routledge.

Mill, R., (2011) A Comprehensive Model of Customer Satisfaction in Hospitality and Tourism: Strategic Implications for Management, International Business \& Economics Research Journal, 1(6)

Nugroho, N. E. (2020). Academic Service Quality of Student Loyalty with Student Satisfaction as Intervening Variables in PTS X. Jurnal Akuntansi, Manajemen dan Ekonomi, 21(4).

Patten, E.; Ozuem, W., \& Howell, K. (2020). Service quality in multichannel fashion retailing: an exploratory study. Information Technology \& People, 33(4), 1327-1356.

Santos, G.; Marques, C. S.; Justino, E., \& Mendes, L. (2020). Understanding social responsibility's influence on service quality and student satisfaction in higher education.Journal of Cleaner Production, 256, 120597.

Sekaran, U., \& Bougie, R. (2016). Research methods for business: A skill building approach. John Wiley \& Sons. 
Shadiev, R., \& Huang, Y. M. (2020). Investigating student attention, meditation, cognitive load, and satisfaction during lectures in a foreign language supported by speech-enabled language translation. Computer Assisted Language Learning, 33(3), 301326.

Srivastav, S.; Gupta, A., \& Garg, V. (2019). Customer Satisfaction in Education: Adopting a new pathway.Journal of Global Economy, 15 (1 (Special), 104-110.

Stankovska, G.; Angelkoska, S.; Osmani, F., \& Grncarovska, S. P. (2017). Job Motivation and Job Satisfaction among Academic Staff in Higher Education. Bulgarian Comparative Education Society.

Tessema, M. T.; Ready, K., \& Yu, W. (2012). Factors affecting college students' satisfaction with major curriculum: Evidence from nine years of data. International Journal of Humanities and Social Science, 2(2), 34-44.

Van Truong, H.; Pham, C. H., \& Vo, N. H. (2016). Service quality and students level of satisfaction in private colleges in Vietnam. International Journal of Financial Research, 7(3), 121-128.

Voorhees, C. M.; Brady, M. K.; Calantone, R., \& Ramirez, E. (2016). Discriminant validity testing in marketing: an analysis, causes for concern, and proposed remedies. Journal of the Academy of Marketing Science, 44(1), 119-134.

Weerasinghe, I. M., \& Dedunu, H. (2017). University Staff, Image and Students' Satisfaction in Selected Regional Universities in Sri Lanka. IOSR Journal of Business and Management (IOSR-JBM), 19(5), 34-37.

Westerbeek, H., \& Shilbury, D. (2003). A Conceptual Model for Sport Services Marketing Research: Integrating Quality, Value and Satisfaction. International Journal of Sports Marketing and Sponsorship. 5. 11-31. 10.1108/IJSMS-05-01-2003-B002. 
Woiceshyn, Jaana \& Daellenbach, Urs. (2018). Evaluating Inductive versus Deductive Research in Management Studies: Implications for Authors, Editors, and Reviewers. Qualitative Research in Organizations and Management: An International Journal. 13. 00-00. 10.1108/QROM-06-2017-1538.

Zavvar, T.; Behrangi, M. R.; Asgarian, M., \& Naderi, E. (2007). Evaluating service quality in Educational Centers of University of Payam Noor in East and West Azerbaijan Provinces from students' point of view. Quarterly journal of research and planning in higher education, 13(46), 67-90. 


\section{ملخص البحث باللفة العربية}

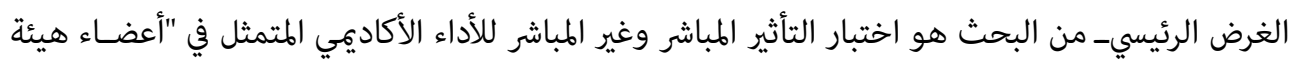

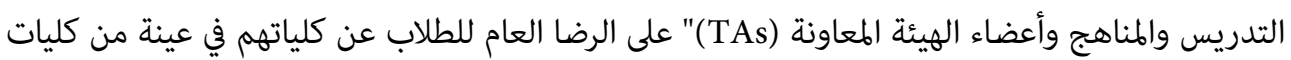

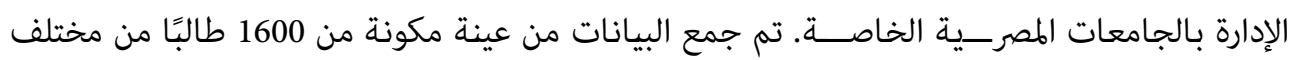

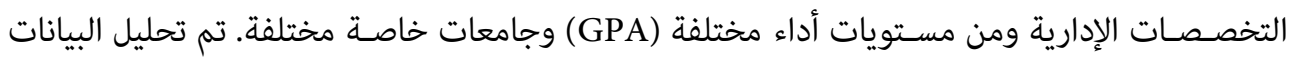

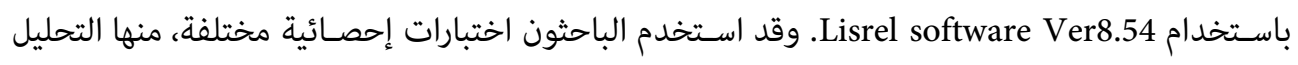

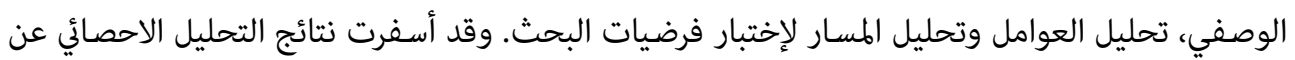

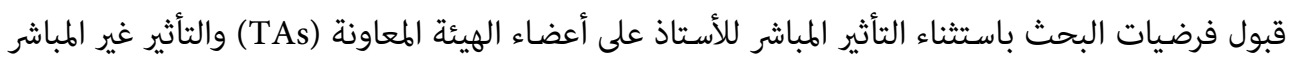

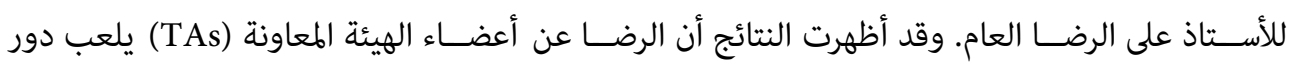

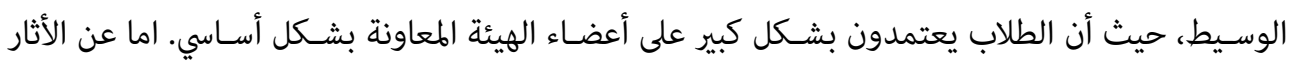

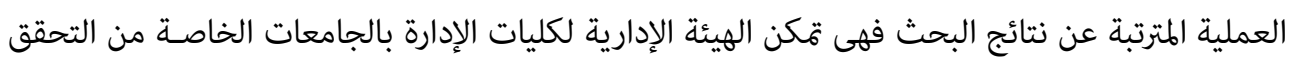

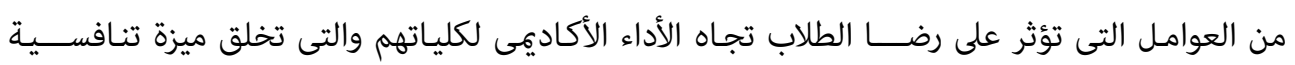

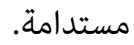
الكلمات المفتاحية: رضا الطلاب - الأداء الأكاديمى - الجامعات الخاصة - تحليل المسار.

\section{Suggested Citation according to APA Style}

El Sheikh, S.; Halim, Y.; Hamdy, H. and El-Deeb, M. (2020). The Impact of Enhancing the Academic Performance on Student Satisfaction of Private Business Faculties: New Business Model for Egyptian Private Universities. Journal of Alexandria University for Administrative Sciences, Faculty of Commerce- Alexandria University 57(4), 1 - 34.

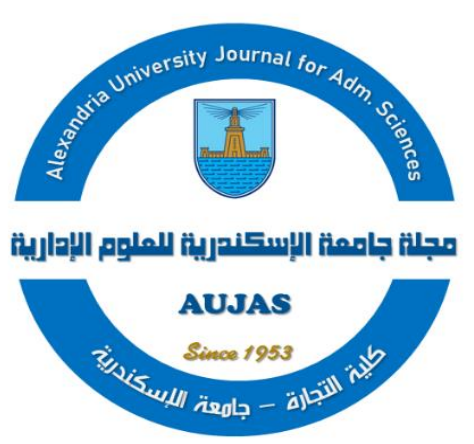

